УдК [796.856.2:796.015.32]-053.5

ISSN (Ukrainian ed. Print) 1991-0177 ISSN (Ukrainian ed. Online) 1999-818X 2021, № 3(83), C.53-59 doi:10.15391/snsv.2021-3.008

\title{
Аналіз змагальної діяльності тхеквондистів 12-14 років
}

\section{Ольга Палій}

Харківська державна академія фізичної культури, Харків, Україна

Мета: провести аналіз показників змагальної діяльності тхеквондистів 12-14 років.

Матеріал і методи: для вирішення поставлених завдань були використані наступні методи дослідження: аналіз і узагальнення науково-методичних джерел та мережі Інтернет; аналіз протоколів та відеозаписів всіх поєдинків спортсменів 12-14 років; методи математичної статистики. Було проаналізовано 117 поєдинків, регламент яких становив 2 раунди по 1,5 хвилини з перервою тривалістю 30 секунд у віковій групі кадети під час проведення Всеукраїнського турніру «Діти України 2020».

Результати: зі всього технічного арсеналу тхеквондисти 12-14 років найчастіше виконують прості удари: «бандал чагі» 61,93\%, «доліо чагі» 13,32\%, «нерьо чагі» 8,18\%, «міро чагі» 5,80\%, «йоп чагі» 4,58\%, «чжумок джиругі» 3,91\%. Складні удари виконують не дуже часто, особливо дівчата. «Твіт чагі» виконують хлопці 1,26\% і дівчата - 0,09\%, «мамдоліо чагі» - хлопці 0,63\% і дівчата 0,08\%, «самбе бандал чагі» - хлопці 0, 19\% і дівчата 0,02\% від всіх нанесених ударів. Із проаналізованих нами 117 поєдинків перемогою за фінальним рахунком закінчилося 92 (78,64\%) від усіх двобоїв. Перемоги у додатковому «золотому» раунді 4 рази - 3,43\%. Перемогою за різницею балів закінчилося 18 двобоїв, що складає 15, 38\%. Перемога за вподобанням суддів - 1 раз (0,85\%), за зауваженням - 1 раз (0,85\%), внаслідок припинення поєдинку рефері - 0,85\%.

Висновки: виявлено, що серед всього арсеналу ударної техніки, найчастіше використовуються прості удари, які виконуються без обертів. Однак, хлопці використовують складну техніку та удар кулаком з більшою частотою у порівнянні з дівчатами, а дівчата ж, у свою чергу, наносять більше ударів в голову. Установлено, що чим більше спортсмен має змагального досвіду, тим менше ударів він виконує, проте, їх ефективність значно вища, що зумовлюється більшою кількістю техніко-тактичних дій та доцільністю їх використання у необхідний момент поєдинку. До того ж спортсмени намагаються більше заробити балів та завершити поєдинок достроково. З'ясовано, що для перемоги у поєдинках необхідна не тільки техніко-тактична підготовка, але й високий рівень прояву фізичних якостей, зокрема витривалості, яка забезпечує виконання технічних дій без зниження ефективності змагальної діяльності.

Ключові слова: тхеквондо ВТФ, змагальна діяльність, аналіз змагальної діяльності, кадети 12-14 років.

\section{Вступ}

Нині є багато підходів до аналізу змагальної діяльності одноборств, проте, не так багато науковців аналізує змагальну діяльність в тхеквондо ВТФ в розділі керугі, яка є найважливішим показником тренованості, техніко-технічної майстерності та психологічної підготовки спортсменів $[1,5,12,13]$. Так, високий темп змагальної діяльності в умовах безпосереднього контакту з супротивником висуває нові потреби вдосконалення процесу підготовки спортсменів. Ефективність виступів тхекондистів на змаганнях залежить від здібності спортсмена протягом всіх поєдинків виконувати техніко-тактичні дії без зниження їх якості. Під час двобою в спортсмена частота сердечних скорочень досягає 160-180 уд/хв, що говорить про прояв такої фізичної якості, як витривалість. У зв'язку зі змінами в правилах, а, отже, і в змагальній діяльності, виникли значні зміни [3, 4, 7, 9].

Галузь змагальної діяльності у тхеквондо ВТФ у різний період часу досліджували І. М. Пашков, А. С. Ровний (2010), О. С. Кощєєв (2004), Лукіна Олена, Стрельчук
Сергій, Gandziarski Krzysztof, Puszczałowska-Lizis Ewa (2019). Одні з останніх розробок Вячеслава Романенка полягають у використанні комп'ютерних технологій для швидкого та зручного відеоаналізу змагальної діяльності за допомогою програми «Martial Arts Video Analysis» $[8,9]$.

Сьогодні існує багато методів вивчення змагальної діяльності, зокрема А. А. Новіков, А. С. Сагалеєв, Г. С. Туманян на прикладі боксу та боротьби запропонували визначати кількість нанесених ударів та ті, що влучили в ціль для того, аби мати змогу оцінити якість змагальної діяльності спортсмена. За отриманими результатами є можливість оцінити ефективність бойових дій $[1,2,14$, $15,16]$. Таким чином, визначивши коефіцієнти атакуючих, захисних дій, змагальної діяльності в певній ваговій категорії, отримана інформація дає змогу проаналізувати в чому певний спортсмен має перевагу, а де поступається суперникам та своєчасно скорегувати навчальнотренувальний процес для отримання високих спортивних досягнень [11, 13, 15, 16]. 
Зв'язок роботи з науковими програмами, планами і темами. Дослідження проводилося відповідно до ініціативних тем науково-дослідних робіт: «Психосенсорна регуляція рухової діяльності спортсменів ситуативних видів спорту» (номер державної реєстрації 0116U008943) та «Науково-методичні основи використання інформаційних технологій при підготовці фахівців галузі фізичної культури та спорту» (номер державної реєстрації 0113U001207).

Мета дослідження - провести аналіз показників змагальної діяльності тхеквондистів 12-14 років.

\section{Матеріал і методи дослідження}

Для вирішення поставлених завдань були використані наступні методи дослідження: аналіз і узагальнення науково-методичних джерел та мережі Інтернет; аналіз протоколів та відеозаписів всіх поєдинків спортсменів 12-14 років; методи математичної статистики.

Було проаналізовано 117 поєдинків, регламент яких становив 2 раунди по 1,5 хвилини з перервою у 30 секунд у віковій групі кадети під час проведення Всеукраїнського турніру «Діти України 2020», який проходив у м. Харків.

Визначено кількість перемог за фінальним рахунком, за різницею балів, за вподобанням, за зауваженням, у додатковому раунді, внаслідок припинення поєдинку рефері; кількість нанесених ударів кожного виду окремо. Були отримані статистичні дані за коефіцієнтами ефективності атакуючих дій, захисних дій, змагальної діяльності.

Проаналізовано коефіцієнти варіації, дисперсія, середнє арифметичне, стандартна похибка середнього арифметичного, стандартне відхилення технічного виконання ударів руками і ногами під час поєдинку.

\section{Результати дослідження}

Умовно ударну техніку можна поділити на дві частини: просту і складну. До простої техніки відносять- ся такі удари: «бандал чагі», «дольо чагі», «йоп чагі», «міро чагі», «нерьо чагі», «чжумок джиругі». До складних: «твіт чагі», «мамдоліо чагі», «самбе бандал чагі». Проаналізувавши отримані дані ударної техніки, на змаганнях були отримані результати, що відображено у табл. 1, 2 та у рис. 1, 2. Так, «бандал чагі» використовується хлопцями 33-45 разів за поєдинок, а дівчатами 31-42 рази. Стандартне відхилення складає 10,14 та 10,99 ударів відповідно. Коефіцієнт варіації становить $30 \%$ у хлопців та $34 \%$ у дівчат. Найчастіше використовується «бандал чагі» $61,93 \%$, як хлопцями 43,5\%, так і дівчатами 18,88\% від загальної кількості нанесених ударів.

«Дольо чагі» використовується хлопцями 6-10 разів, а дівчатами 9-19 раз. Стандартне відхилення цього удару складає 3,91 у хлопців та 6,63 у дівчат. Коефіцієнт варіації склав 66\% у хлопців та $59 \%$ у дівчат. За результатами дослідження, хлопці використовують 7,58\% від усіх ударів, а дівчата $5,74 \%$, а загалом $13,32 \%$. Таким чином, ми бачимо, що «дольо чагі», тобто удар в голову, частіше виконують дівчата, ніж хлопці.

Як бачимо, протягом всього поєдинку «нерьо чагі» хлопці виконують 4-11 раз, а дівчата 6-13 раз. Стандартне відхилення складає 3,98 удари у хлопців та 3,68 у дівчат. Коефіцієнт варіації у хлопців склав $76 \%$ та $61 \%$ у дівчат відповідно. «Нерьо чагі» використовується хлопцями $5,33 \%$, а дівчатами 2,85\%. Отже, цей удар використовується рідше, ніж попередній. Так, загальний показник використання складає 8,18\%, проте, хлопці використовують його частіше (5,33\%), а дівчата лише 2,85\% від усієї ударної техніки.

«Міро чагі» хлопці використовують 5-8 разів, а дівчата 4-10 разів під час поєдинку. Стандартне відхилення складає 2,83 удари у хлопців та 3,75 у дівчат. Коефіцієнт варіації у хлопців склав $73 \%$ та $75 \%$ у дівчат відповідно. «Міро чагі» використовують загалом 5,8\% від загальної кількості нанесених ударів, проте, хлопці частіше (4,04\%), ніж дівчата (1,76\%).

Таблиця 1

Показники об'єму техніки тхеквондистів, яка використовується під час змагальної діяльності (хлопці $n_{1}=103$; дівчата $n_{2}=48$ ), удари

\begin{tabular}{|c|c|c|c|c|c|c|c|c|c|c|}
\hline & & $\begin{array}{c}\text { Бандал } \\
\text { чагі }\end{array}$ & $\begin{array}{c}\text { Дольо } \\
\text { чагі }\end{array}$ & $\begin{array}{l}\text { Йоп } \\
\text { чагі }\end{array}$ & $\begin{array}{c}\text { Мipo } \\
\text { чагі }\end{array}$ & $\begin{array}{l}\text { Твіт } \\
\text { чагі }\end{array}$ & $\begin{array}{c}\text { Мамдоліо } \\
\text { чагі }\end{array}$ & $\begin{array}{c}\text { Самбе } \\
\text { бандал } \\
\text { чагі }\end{array}$ & $\begin{array}{l}\text { Нерьо } \\
\text { чагі }\end{array}$ & $\begin{array}{l}\text { Чжумок } \\
\text { джиругі }\end{array}$ \\
\hline \multirow{2}{*}{$\begin{array}{c}\bar{X} \pm \\
\mathrm{m}\end{array}$} & Хл & $\begin{array}{c}33,52 \pm \\
2,78\end{array}$ & $\begin{array}{c}6,00 \pm \\
1,06\end{array}$ & $\begin{array}{l}3,4 \pm \\
0,69\end{array}$ & $\begin{array}{c}3,85 \pm \\
0,82\end{array}$ & $\begin{array}{l}2,1 \pm \\
0,51\end{array}$ & $\begin{array}{c}1,79 \pm \\
0,50\end{array}$ & $\begin{array}{c}1,44 \pm \\
0,74\end{array}$ & $\begin{array}{c}5,14 \pm \\
1,40\end{array}$ & $\begin{array}{c}4,19 \pm \\
0,87\end{array}$ \\
\hline & Дів & $\begin{array}{c}31,55 \pm \\
4,38\end{array}$ & $\begin{array}{c}9,10 \pm \\
2,97\end{array}$ & $\begin{array}{l}4,5 \pm \\
1,15\end{array}$ & $\begin{array}{c}4,84 \pm \\
1,92\end{array}$ & & $\begin{array}{c}1,06 \pm \\
0,11\end{array}$ & & $\begin{array}{c}6,36 \pm \\
1,41\end{array}$ & $\begin{array}{c}2,99 \pm \\
1,03\end{array}$ \\
\hline \multirow{2}{*}{$\sigma$} & Хл & 10,14 & 3,91 & 2,47 & 2,83 & 1,46 & 1,11 & 1,21 & 3,98 & 2,68 \\
\hline & Дів & 10,99 & 6,63 & 2,99 & 3,75 & & 0,19 & & 3,68 & 2,24 \\
\hline \multirow[b]{2}{*}{$\sigma^{2}$} & Хл & 108,62 & 16,88 & 9,33 & 9,46 & 2,73 & 1,44 & 1,91 & 18,81 & 8,35 \\
\hline & Дів & 129,57 & 56,26 & $\begin{array}{c}14,1 \\
1\end{array}$ & 18,21 & & 0,17 & & 17,21 & 6,10 \\
\hline \multirow{2}{*}{$\begin{array}{l}\mathrm{V}( \\
\%)\end{array}$} & Хл & 30 & 66 & 78 & 73 & 69 & 60 & 60 & 76 & 70 \\
\hline & Дів & 34 & 59 & 57 & 75 & & 22 & & 61 & 68 \\
\hline
\end{tabular}




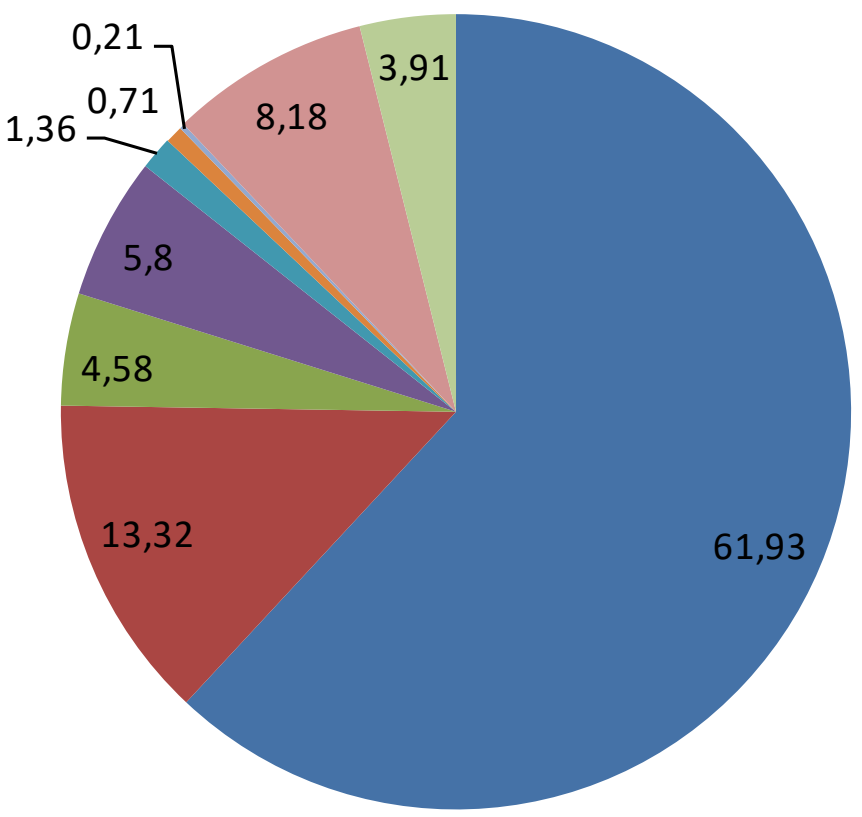

\author{
бандал чагі \\ доліо чагі \\ йоп чагі \\ міро чагі \\ твіт чагі \\ мамдоліо чагі \\ самбе бандаль чагі \\ нерьо чагі \\ чжумок джиругі
}

Рис. 1. Використання об'єму техніки під час змагального поєдинку, \%

Під час поєдинку «йоп чагі» хлопці виконують 4-8 разів, а дівчата 3-7 разів. За показником стандартного відхилення «йоп чагі» у хлопців має 3,91 удар та 6,63 удари у дівчат. Коефіцієнт варіації у хлопців має $78 \%$, а у дівчат 57\%. Загалом, виходячи з отриманих даних, «йоп чагі» використовують у кількості 4,58\% від всієї кількості ударів, при цьому хлопці 2,91\%, а дівчата $1,67 \%$.

«Чжумок джиругі», тобто удар рукою, хлопці використовують 4-8 разів, а дівчата 2-6 разів. Стандартне відхилення складає 2,68 удари у хлопців та 2,24 у дівчат. Коефіцієнт варіації у хлопців склав $70 \%$ та $68 \%$ у дівчат. «Чжумок джиругі» більшим попитом користується у хлопців $3,21 \%$, а у дівчат цей показник складає лише 0,69\%. Загалом удар кулаком використовується 3,91\% від всіх ударів.

«Твіт чагі» протягом поєдинку хлопці використовують 2-4 рази. Стандартне відхилення має 1,46 та коефіцієнт варіації 69\% також у хлопців. Так, «твіт чагі» займає $1,36 \%$ від всіх ударів, у хлопців використання даного удару складає $1,26 \%$, а у дівчат лише $0,09 \%$.
«Мамдоліо чагі» хлопці під час поєдинку б'ють 1-3 рази та 1-2 рази дівчата. Стандартне відхилення складає 1,11 у хлопців та 0,19 у дівчат. Коефіцієнт варіації у хлопців склав $60 \%$ та $22 \%$ у дівчат. «Мамдоліо чагі» складає 0,71\% від всіх нанесених ударів у хлопців 0,63\% та $0,08 \%$ у дівчат.

«Самбе бандаль чагі» використовується хлопцями 1-2 рази. Стандартне відхилення складає 1,21 у хлопців. Коефіцієнт варіації у хлопців склав 60\%. «Самбе бандаль чагі» складає 0,21\% від всіх ударів у хлопців 0,19\% та $0,02 \%$ у дівчат.

Складна техніка ударів з обертами, такі як «твіт чагі», «мамдоліо чагі» та «самбе бандаль чагі» використовується дуже рідко, проте, хлопці, не зважаючи на складність виконання, частіше їх використовують, ніж дівчата. Отже, після аналізу отриманих даних щодо використання об'єму ударів можна сказати, що хлопці виконують більш різноманітнішу та складнішу техніку в поєдинках та значно частіше б'ють рукою, а дівчата більшу перевагу віддають простій техніці, але при цьому кількість нанесених ударів в голову більша.

Таблиця 2

Порівняння використання ударів між хлопцями і дівчатами

\begin{tabular}{|c|c|c|c|c|c|c|c|c|c|c|}
\hline & & $\begin{array}{c}\text { Бандал } \\
\text { чагі }\end{array}$ & $\begin{array}{c}\text { Дольо } \\
\text { чагі }\end{array}$ & $\begin{array}{c}\text { Йоп } \\
\text { чагі }\end{array}$ & $\begin{array}{c}\text { Міро } \\
\text { чагі }\end{array}$ & $\begin{array}{c}\text { Твіт } \\
\text { чагі }\end{array}$ & $\begin{array}{c}\text { Мамдоліо } \\
\text { чагі }\end{array}$ & $\begin{array}{c}\text { Самбе } \\
\text { бандал } \\
\text { чагі }\end{array}$ & $\begin{array}{c}\text { Нерьо } \\
\text { чагі }\end{array}$ & $\begin{array}{c}\text { Чжумок } \\
\text { джиругі }\end{array}$ \\
\hline \multirow{2}{*}{$\%$} & Хл & 43,05 & 7,58 & 2,91 & 4,04 & 1,26 & 0,63 & 0,19 & 5,33 & 3,21 \\
\cline { 2 - 10 } & Дів & 18,88 & 5,74 & 1,67 & 1,76 & 0,09 & 0,08 & 0,02 & 2,85 & 0,69 \\
\hline$\Sigma \%$ & & 61,93 & 13,32 & 4,58 & 5,80 & 1,36 & 0,71 & 0,21 & 8,18 & 3,91 \\
\hline
\end{tabular}




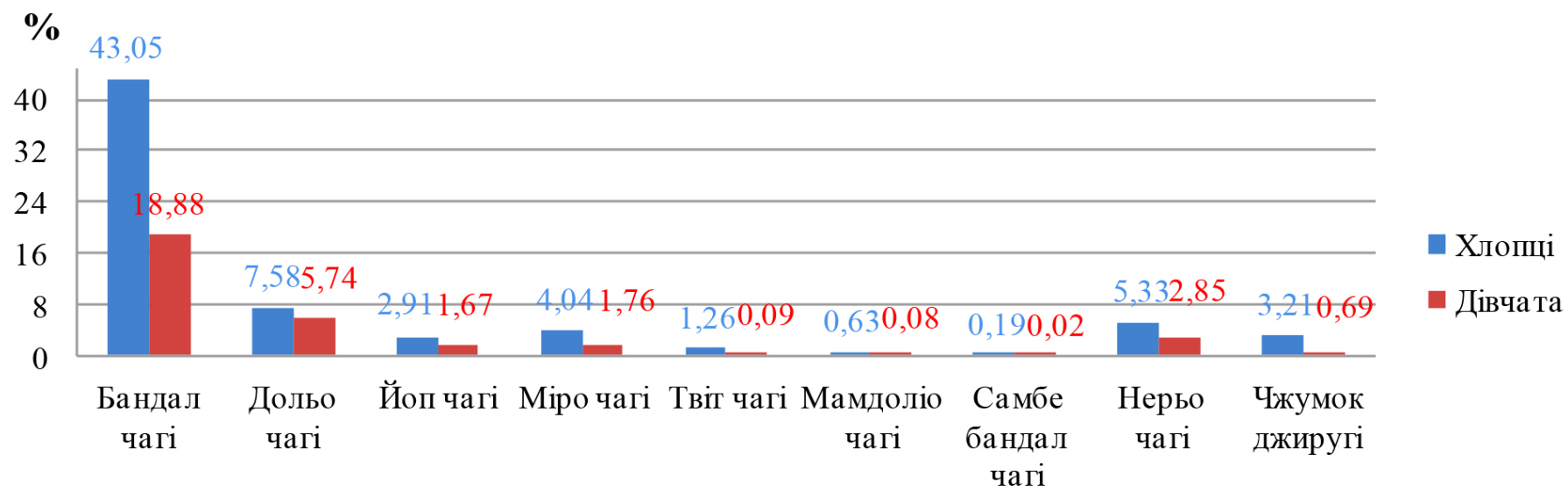

Рис. 2. Порівняння використання ударів хлопцями і дівчатами, (\%)

Після аналізу коефіцієнтів ефективності змагальної діяльності тхеквондистів були отримані наступні результати, що відображено у табл. 3. Кількість нанесених ударів у хлопців становить $48,48 \pm 3,42$, а у дівчат $57,15 \pm 8,56$ ударів. Стандартна помилка у хлопців становить 13,09, а у дівчат 12,91 ударів. При цьому вибірки у хлопців (32\%) та дівчат (25\%) не стабільні в своїх показниках. Це говорить про те, що у кожному двобої кількість нанесених ударів відрізняється за рахунок того, що суперники мають різну спортивну кваліфікацію.

Коефіцієнт ефективності атакуючих дій (КЕАД) у

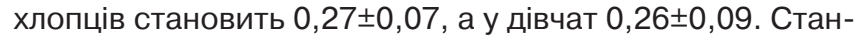
дартне відхилення дорівнює 0,15 у хлопців та 0,14 у дівчат. Коефіцієнт варіації у даній вибірці становить 54\% та 59\% відповідно. Даний коефіцієнт має не стабільні показники за генеральною сукупністю, а це говорить про те, що атакуючі дії у тхеквондо не завжди приносять бали, проте, спонукають суперника до контратаки, а, отже, до активних техніко-тактичних дій.

Коефіцієнт варіації захисних дій (КЕЗахД) показує кількість ударів суперника, які були відображені. Під час аналізу даних були отримані наступні результати: у хлоп-

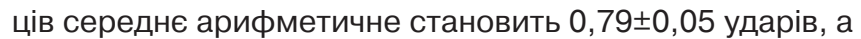

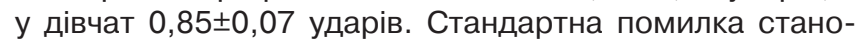

вить 0,13 у хлопців та 0,10 у дівчат, що говорить про невелике відхилення від середнього арифметичного. Коефіцієнт варіації дорівнює $17 \%$ та $12 \%$, а, отже, мають середню розбіжність між показниками.

Коефіцієнт ефективності змагальних дій (КЕЗмагД) говорить про те на скільки атакуючі та захисні дії були ефективними під час поєдинку. Середнє арифметичне значення у хлопців становить $1,08 \pm 0,03$, а у дівчат $1,11 \pm 0,08$. Стандартна помилка у хлопців становить 0,08 , а у дівчат 0,13. Коефіцієнт варіації у хлопців дорівнює 7\%, що говорить про стабільність показників генеральної сукупності та $12 \%$ у дівчат, де стабільність показників є середньо стабільною.

Щільність поєдинку відображає час поєдинку, який було витрачено спортсменом безпосередньо на виконання атакуючих або захисних дій. В даних змаганнях сума часу двох раундів дорівнювала 3 хвилини. Так, да-

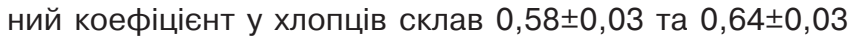
у дівчат. Стандартна помилка у хлопців дорівнює 0,12 та 0,09 у дівчат. Коефіцієнт варіації склав 20\% та $16 \%$ відповідно, що говорить про середню стабільність показників.

Аналізуючи отримані дані щодо перемог у поєдинках, були отримані наступні результати (табл. 4).

Таблиця 3

Коефіцієнти ефективності змагальної діяльності тхеквондистів

\begin{tabular}{|c|c|c|c|c|c|c|}
\hline Показник & Стать & КНУ & КЕАД & КЕЗахД & КЕЗмагД & $\begin{array}{c}\text { Щільність } \\
\text { поєдинку }\end{array}$ \\
\hline \multirow{2}{*}{$\bar{X} \pm \mathrm{m}$} & Хл. & $48,48 \pm 3,42$ & $0,27 \pm 0,07$ & $0,79 \pm 0,05$ & $1,08 \pm 0,03$ & $0,58 \pm 0,03$ \\
\cline { 2 - 7 } & Дів. & $57,15 \pm 8,56$ & $0,26 \pm 0,09$ & $0,85 \pm 0,07$ & $1,11 \pm 0,08$ & $0,64 \pm 0,03$ \\
\hline \multirow{2}{*}{$\sigma$} & Хл. & 13,09 & 0,15 & 0,13 & 0,08 & 0,12 \\
\cline { 2 - 7 } & Дів. & 12,91 & 0,14 & 0,10 & 0,13 & 0,09 \\
\hline \multirow{2}{*}{$\sigma^{2}$} & Хл. & 187,93 & 0,03 & 0,02 & 0,01 & 0,02 \\
\cline { 2 - 7 } & Дів. & 185,75 & 0,03 & 0,01 & 0,03 & 0,01 \\
\hline \multirow{2}{*}{ V(\%) } & Хл. & 32 & 54 & 17 & 7 & 20 \\
\cline { 2 - 7 } & Дів. & 25 & 59 & 12 & 12 & 16 \\
\hline
\end{tabular}

Примітка:

КНУ - кількість нанесених ударів; КЕАД - коефіцієнт ефективності атакуючих дій;

КЕЗахД - коефіцієнт ефективності захисних дій; КЕЗмагД - коефіцієнт ефективності змагальних дій 


\section{СЛОБОЖАНСЬКИЙ НАУКОВО-СПОРТИВНИЙ ВІСНИК}

Таблиця 4

Якісний показник перемог у поєдинках

\begin{tabular}{|c|c|c|c|c|}
\hline & Показники & Кількість & $\%$ & $\begin{array}{c}\text { Всього } \\
\text { поєдинків }\end{array}$ \\
\hline 1 & Перемога за фінальним рахунком & 92 & 78,64 & \multirow{6}{*}{117} \\
\hline 2 & Перемога за різницею балів & 18 & 15,38 & \\
\hline 3 & Перемога за вподобанням & 1 & 0,85 & \\
\hline 4 & Перемога за зауваженням & 1 & 0,85 & \\
\hline 5 & Перемога у додатковому раунді & 4 & 3,43 & \\
\hline 6 & $\begin{array}{c}\text { Перемога внаслідок припинення поєдинку } \\
\text { рефері }\end{array}$ & 1 & 0,85 & \\
\hline
\end{tabular}

Перемогою за фінальним рахунком закінчилося 92 поєдинки, що складає 78,64\% від всіх двобоїв. Перемогою за різницею балів, тобто відрив від суперника у рахунку на 20 та більше балів, закінчилося 18 двобоїв, що складає 15,38\%. Перемогою за вподобанням суддів закінчився лише один поєдинок, а це 0,85\% від всіх. Перемоги у додатковому «золотому» раунді трапилися 4 рази, що склало 3,43\%. Перемога за зауваженням теж була лише одна та склала 0,85\%. Перемога внаслідок припинення поєдинку рефері була одна та склала 0,85\% від усіх поєдинків.

\section{Висновки / Дискусія}

Серед усього арсеналу ударної техніки найчастіше використовуються прості удари, які виконуються без обертів. Однак, хлопці використовують складну техніку та удар кулаком з більшою частотою, у порівнянні з дівчатами, а дівчата ж, у свою чергу, наносять більше ударів в голову.

Чим більше спортсмен має змагального досвіду, тим менше ударів він виконує, проте, їх ефективність значно вища, що зумовлюється більшою кількістю техніко-так- тичних дій та доцільністю їх використання у необхідний момент поєдинку. Також спортсмени намагаються більше заробити балів та завершити поєдинок достроково.

Для того, аби вигравати поєдинок необхідна не тільки техніко-тактична підготовка, але й високий рівень прояву фізичних якостей, зокрема витривалості, яка забезпечує виконання технічних дій без зниження ефективності змагальної діяльності.

З усіх проаналізованих поєдинків 78\% перемог було за кількістю зароблених балів, що свідчить про те, що конкуренція у вагових категоріях досить висока та спортивна досвідченість і кваліфікація спортсменів приблизно однакова.

Перспективи подальших досліджень у даному напрямку будуть спрямовані на аналіз поєдинків в тхеквондо ВТФ за раундами та виявлення динаміки змін щільності протягом раундів, що дасть змогу визначити механізми, які впливають на перемогу з урахуванням прояву витривалості спортсмена та надати інформацію щодо вдосконалення ефективності змагальної діяльності тхеквондистів 12-14 років.

Конфлікт інтересів. Автори заявляють, що відсутній конфлікт інтересів, який може сприйматись таким, що може завдати шкоди неупередженості статті.

Джерела фінансування. Ця стаття не отримала фінансової підтримки від державної, громадської або комерційної організації.

\section{Список посилань}

1. Арансон М. В., Шустин Б. Н. (2018), «Актуальные направления анализа соревновательной деятельности единоборцев», Педагогические науки, Выпуск 9 (75), С. 99-101.

2. Карпов М. А., Мукалляпов А. Г., Воронцов В.В. (2017), «Специальные способности тхеквондистов в модели соревновательной деятельности», Международный научно-исследовательский журнал, № 4(58), С. 29-31.

3. Кощєєв О. С. (2004), «Змагальна діяльність в тхеквондо», Молода спортивна наука України, №8, Т.1, С. $204-207$.

4. Лукіна Олена, Стрельчук Сергій, Gandziarski Krzysztof, Puszczałowska-Lizis Ewa (2019), «Аналіз змагальної діяльності тхеквондистів-кадетів до та після змін правил (версія ВТФ)», Спортивний вісник Придніпров'я, №3, С. 19-28.

5. Новиков А. А. (2003), Основы спортивного мастерства. М.:ВНИИФК, 208 с.

6. Пашков І. М., Ровний А. С. (2010), «Ефективність змагальної діяльності спортсменів спеціалізації тхеквондо (ВТФ)», Слобожанський науково-спортивний вісник, №4, С. 60-63.

7. Пашков І. М., Палій О. В. (2019), «Особливості функціональних здібностей тхеквондистів», Єдиноборства, №2 (12), С. $39-47$.

8. Романенко В. В., Голоха В. Л., Алексєєв А. Ф., Коваленко Ю. М. (2020), «Методика оцінки змагальної діяльності одноборців з використанням комп’ютерних технологій», Слобожанський науково-спортивний вісник, №6(80), С. 65-72.

9. Романенко В. В., Голоха В. Л., Веретельникова Н. А. (2018), «Оценка и анализ подготовленности квалифицированных тхеквондистов», Єдиноборства, №1, С. 58-69.

10. Сагалеев А. С., Калмыков С. В., Дагбаев Б. В. (2007), Соревновательная деятельность в спортивной борьбе. Улан-Удэ: Издательство Бурятского госуниверситета, 204 с. 
11. Туманян Г. С. (1984), Спортивная борьба: отбор и планирование. М.: Физкультура и спорт, 144 с.

12. Chong Lee (1978), Kicks for competition. O'Hara Publications INC USA, $145 \mathrm{p}$.

13. Kruszewski A., Kuzmicki S., Podchul A., Kruszewski M. (2014), «Effect of change since the sport regulations on the fight of taekwondo female players on the example of Beijing Olimpic Tournaments 2008 and London 2012», Journal of Combat Sports and Martial Arts, Vol.5, № 2(2), pp. 97-100.

14. Manescardi C., Lopez J. A., Falco C., et al. (2015), «Tactical aspect so fanational university taekwondo championship in relation to round and match out come», J Strength Cond Res, № 29(2), pp. 466-471.

15. Santos V.G.F., F. de Oliveira Pires, Bertuzzi R. et al. (2014), «Relationship between attack and pause in world taekwondo championship contests: effects of gender and weight category», Muscles, Ligaments and Tendons Journal, № 4(2), pp. 127-131.

16. Wohlin S. A. (1989), «Biomechanical Description of the Taekwondo Turning Hook Kick», Unpublished Master's Thesis, Montana State University, $231 \mathrm{p}$.

Стаття надійшла до редакції: 13.05.2021 р.

Опубліковано: 23.06.2021 р.

Аннотация. Ольга Палий. Анализ соревновательной деятельности тхеквондистов 12-14 лет. Цель: провести анализ показателей соревновательной деятельности тхэквондистов 12-14 лет. Материал и методы: для решения поставленных задач были использованы следующие методы исследования: анализ и обобщение научно-методических источников и сети Интернет; анализ протоколов и видеозаписей всех поединков спортсменов 12-14 лет, методы математической статистики. Было проанализировано 117 поединков, регламент которых составлял 2 раунда по 1,5 минуты с перерывом в 30 секунд в возрастной группе кадеты во время проведения Всеукраинского турнира «Дети Украины 2020». Результаты: из всего технического арсенала тхеквондисты 12-14 лет чаще всего выполняют простые удары: «бандал чаги» 61,93\%, «доли чаги» 13,32\%, «нерё чаги» 8, 18\%, «миро чаги» 5,80\%, «йоп чаги» 4,58\%, «чжумок джируги» 3,91\%. Сложные удары выполняют не очень часто, особенно девушки. «Твит чаги» выполняют парни 1,26\% и девушки 0,09\%, “мамдолио чаги» - ребята 0,63\% и девушки 0,08\%, “самбе бандал чаги» - ребята 0,19\% и девушки 0,02\% от всех нанесенных ударов. Из проанализированных 117 поединков победой по финальному счету закончилось $92(78,64 \%)$ от всех поединков. Победы в дополнительном «золотом» раунде встречались 4 раза (3,43\%). Победой по разнице баллов закончилось 18 поединков, что составляет 15,38\%. Победа по предпочтениям судей - 1 раз (0,85\%), по замечанию - 1 раз (0,85\%), вследствие прекращения поединка рефери 1 раз (0,85\%). Выводы: выявлено, что среди всего арсенала ударной техники чаще всего используются простые удары, которые выполняются без оборотов. Однако ребята используют сложную технику и удар кулаком с большей частотой, по сравнению с девушками, а девушки же, в свою очередь, наносят больше ударов в голову. Установлено, что чем больше спортсмен имеет соревновательного опыта, тем меньше ударов он выполняет, однако, их эффективность значительно выше, что обусловлено большим количеством технико-тактических действий и целесообразностью их использования в необходимый момент поединка. К тому же, спортсмены стараются больше заработать баллов и завершить поединок досрочно. Выяснено, что для выиграша поединков необходима не только техникотактическая подготовка, но и высокий уровень проявления физических качеств, в частности выносливости, которая обеспечивает выполнение технических действий без снижения эффективности соревновательной деятельности.

Ключевые слова: тхэквондо ВТФ, соревновательная деятельность, анализ соревновательной деятельности, кадеты $12-$ 14 лет.

Abstract. Olha Palii. Analysis of the competitive activity of taekwondo athletes 12-14 years old. Purpose: to analyze the indicators of competitive activity of taekwondo athletes 12-14 years. Material and methods: the following research methods were used to solve the tasks: analysis and generalization of scientific and methodological sources and Internet; analysis of protocols and videos of all fights of athletes aged 12-14; methods of mathematical statistics. 117 matches were analyzed, the schedule of which was 2 rounds of 1,5 minutes with a break of 30 seconds in the age group of cadets, during the All-Ukrainian tournament "Children of Ukraine 2020 ". Results: from all technical arsenal taekwondo players of 12-14 years most often carry out simple kicks: «bandal chagi» - 61,93\%, «dolio chagi» - 13,32\%, «neryo chagi» - 8,18\%, «miro chagi» - 5,80\%, "yop chagi» - 4,58\%, "dzhumok girugi»- 3,91\%. Complex kicks are not performed very often, especially girls. "Twit chagi» boys - 1,26\% and girls 0,09\%, «mamdolio chagi» - boys 0,63\% and girls 0,08\%, "sambe bandal chagi» - boys 0,19\% and girls 0,02\% from all kicks. Of the 117 matches analyzed, 92(78.64\%) of all matches ended in victory in the final. Wins in the additional "golden" round 4 times - 3,43\%. The victory on the difference of points ended 18 matches, which is $15,38 \%$. Victory according to the referee's preference - 1 time $(0,85 \%)$, according to comments - 1 time $(0,85 \%)$, due to the termination of the match by the referee (0,85\%). Conclusions: among the whole arsenal of percussion techniques, simple kicks are most often used, which are performed without revolutions. However, boys use sophisticated technique and punch more often than girls, and girls, in turn, strike more kicks to the head. The more competitive experience an athlete has, the fewer kicks he performs, but their effectiveness is much higher, which is due to the greater number of technical and tactical actions and the expediency of their use at the right time of the fight. Also, athletes try to earn more points and finish the fight early. In order to win a match requires not only technical and tactical training, but also a high level of manifestation of physical qualities, including endurance, which ensures the performance of technical actions without reducing the effectiveness of competitive activities.

Keywords: taekwondo WTF, competitive activity, analysis of competitive activity, cadets 12-14 years old.

\section{References}

1. Aranson, M. V., Shustyn, B. N. (2018), «Actual directions of the analysis of the competitive activity of combatants», Pedahohycheskye nauky, Vy’pusk 9(75), pp. 99-101. (in Russ.)

2. Karpov, M. A., Mukalliapov, A. H., Vorontsov, V. V. (2017), «Special abilities of taekwondo fighters in the model of competitive activity», Mezhdunarodnыi nauchno-yssledovatelskyi zhurnal, No. 4(58), pp. 29-31. (in Russ.)

3. Koshchieiev, O. S. (2004), "Competitive activity in taekwondo», Moloda sportyvna nauka Ukrainy, No. 8, T.1, pp. 204-207. (in Ukr.)

4. Lukina, Olena, Strelchuk, Serhii, Gandziarski, Krzysztof, Puszczałowska-Lizis, Ewa (2019), «Analysis of competitive activity of taekwondo cadets before and after the change of rules (WTF version)», Sportyvnyi visnyk Prydniprovia, No. 3, pp. 19-28. (in Ukr.)

5. Novykov, A. A. (2003), Osnovы sportyvnoho masterstva. M: VNYYFK, 208 p. 


\section{СЛОБОЖАНСЬКИЙ НАУКОВО-СПОРТИВНИЙ ВІСНИК}

6. Pashkov, I. M., Rovnyi, A. S. (2010), «The effectiveness of competitive activities of athletes specializing in taekwondo (WTF)», Slobozhanskyi naukovo-sportyvnyi visnyk, No. 4, pp. 60-63. (in Ukr.)

7. Pashkov, I. M., Palii, O. V. (2019), «Features of functional abilities of taekwondo fighters», Yedynoborstva, No. 2 (12), pp. 3947. (in Ukr.)

8. Romanenko, V. V., Holokha, V. L., Aleksieiev, A. F., Kovalenko, Yu. M. (2020), «Methods of assessing the competitive activities of wrestlers using computer technology», Slobozhanskyi naukovo-sportyvnyi visnyk, No. 6(80), pp. 65-72. (in Ukr.)

9. Romanenko, V. V., Holokha, V. L., Veretelnykova, N. A. (2018), «Assessment and analysis of the preparedness of qualified taekwondo athletes», Yedynoborstva, No.1, pp. 58-69. (in Russ.)

10. Sagaleev, A. S., Kalmy`kov, S. V., Dagbaev, B. V. (2007), Sorevnovatel'naya deyatel'nost' v sportivnoj bor 'be. Ulan-Ude`: Izdatel'stvo Buryatskogo gosuniversiteta, 204 p. (in Russ.)

11. Tumanyan G. S. (1984), Sportivnaya bor 'ba: otbor i planirovanie. M.: Fizkul'tura i sport, 144 p. (in Russ.)

12. Chong, Lee (1978), Kicks for competition. O'Hara Publications INC USA, 145 p. (in Eng.)

13. Kruszewski, A., Kuzmicki, S., Podchul, A., Kruszewski, M. (2014), «Effect of change since the sport regulations on the fight of taekwondo female players on the example of Beijing Olimpic Tournaments 2008 and London 2012», Journal of Combat Sports and Martial Arts, Vol.5, № 2(2), pp. 97-100. (in Eng.)

14. Manescardi, C., Lopez, J. A., Falco, C., et al. (2015), «Tactical aspect so fanational university taekwondo championship in relation to round and match out come», J Strength Cond Res, № 29(2), pp. 466-471. (in Eng.)

15. Santos, V.G.F., F. de Oliveira Pires, Bertuzzi, R. et al. (2014), «Relationship between attack and pause in world taekwondo championship contests: effects of gender and weight category», Muscles, Ligaments and Tendons Journal, № 4(2), pp. 127-131. (in Eng.)

16. Wohlin S. A. (1989), «Biomechanical Description of the Taekwondo Turning Hook Kick», Unpublished Master's Thesis, Montana State University, 231 p. (in Eng.)

Received: 13.05.2021.

Published: 23.06.2021.

\section{Відомості про авторів / Information about the Authors}

Палій Ольга Віталіївна: аспірантка кафедри одноборств; Харківська державна академія фізичної культури: вул.. Клочківська 99, м. Харків, 61058, Україна.

Палий Ольга Витальевна: аспирантка кафедры единоборств; Харьковская государственная академия физической культуры: ул. Клочковская 99, г. Харьков, 61058, Украина.

Olha Palii: graduate student of the Department of Martial Arts; Klochkivska 99, Kharkiv, 61058, Ukraine.

ORCID: https://orcid.org/0000-0002-8593-2549

E-mail: olgapalyua@gmail.com 